Article

\title{
Genetic Diversity and Seed Quality of the "Badda" Common Bean from Sicily (Italy)
}

\section{Lucia Lioi * and Angela Rosa Piergiovanni}

Istituto di Bioscienze e Biorisorse, Consiglio Nazionale delle Ricerche, via Giovanni Amendola 165/A, Bari 70126, Italy; E-Mail: angelarosa.piergiovanni@ibbr.cnr.it

* Author to whom correspondence should be addressed; E-Mail: lucia.lioi@ibbr.cnr.it;

Tel.: +39-080-5583400; Fax: +39-080-5587566.

Received: 4 October 2013; in revised form: 29 November 2013 / Accepted: 2 December 2013 /

Published: 6 December 2013

\begin{abstract}
The genetic structure of the "Badda" common bean cultivated at Polizzi Generosa, a village of Sicily (Palermo, Italy), was investigated using biochemical and molecular markers. Seed storage protein analysis by using SDS-PAGE, confirmed the attribution to the Andean gene pool. Simple Sequence Repeats (SSR) (or microsatellite) molecular markers provided useful information on genetic variation and relationships between "Badda bianco" and "Badda nero" morphotypes. Based on SSR data, the nine accessions examined were grouped in three sub-clusters. The first sub-cluster included all the accessions belonging to the "Badda bianco". Conversely, "Badda nero" was constituted by two well-distinguished sub-clusters, one of them forming a well-separated branch. This result suggests that two constitutive nuclei contributed to the genetic background of "Badda nero". Moreover, technological and nutritional data evidenced a good seed protein content (mean value $240.7 \mathrm{~g} \mathrm{~kg}^{-1}$ ) and differences in seed hydration rate among accessions. Knowledge of genetic structure appear to be fundamental in planning safeguard strategies of an appreciate landrace such as the "Badda" bean.
\end{abstract}

Keywords: landrace; on-farm conservation; phaseolin; Phaseolus vulgaris; seed quality; SSR 


\section{Introduction}

Legumes occupy an important place in human nutrition being a good source of proteins, dietary fiber, starch, minerals and vitamins. They are characterized by global adaptability, high genotypic and phenotypic diversity, and are used in a variety of food preparations. Among pulses, the common bean (Phaseolus vulgaris L.) is recognized as the most widely grown species being cultivated extensively in the five continents and spanning from $52^{\circ} \mathrm{N}$ to $32^{\circ} \mathrm{S}$ latitude, and from near sea level in the continental USA and Europe, to more than $3000 \mathrm{~m}$ asl (above sea level) in Andean South America. After the discovery of Americas, the common bean rapidly spread into Europe and its cultivation has been practiced uninterruptedly for five centuries. This produced a myriad of landraces well adapted to the new agro-environments. A significant number of these landraces are still cultivated, mainly in the marginal areas of Italy, the Iberian peninsula and Greece [1-5]. Here, after each harvest, farmers store a portion of seeds for sowing the following year. This practice, known as on-farm conservation, allows the survival of precious plant genetic resources without economical charges for governmental institutions [6].

Historical investigations provide evidence of a long-lasting tradition of common bean cultivation in Italy [1]. In the last decades, several landraces have been investigated to promote their safeguard, valorization, and on farm conservation [7-9]. Although the attention devoted by researchers to common bean landraces has greatly increased, studies on this topic are far from being exhaustive. Recent collecting missions carried out in the hilly environments of the Nebrodi mountains and the Madonie natural park (north Sicily), evidenced that several landraces are cultivated in marginal areas, where the agriculture is still based on traditional agro-techniques [10,11].

For more than two centuries, at Polizzi Generosa, a village situated in the Madonie natural park, cultivation of the "Badda" common bean is practiced (Figure 1). In the local language "Badda" means "ball" and refers to the round seed shape. This name is usually used by local farmers to indicate local varieties characterized by bicolored seeds. Two morphotypes are easily distinguished: one named "Badda bianco" (white Badda) with background cream and a spot from light brown to brown, and the other with cream background, but a spot from violet to black, known as "Badda nero" (black Badda) or sometimes "Munachedda". Plants have a climbing habit, and are traditionally cultivated in small clay soil fields, located between 700 and $900 \mathrm{~m}$ asl. The sowing period ranges from the second decade of June to the second decade of July in dependence of field elevation; the harvest is conducted from October to November. The harvest is mainly sold in regional markets as dry seed, but also as green pod ("fasoli virdi").

The attention of local community towards "Badda" bean safeguard has brought about some initiatives such as: the inclusion in the list of traditional agro-food products held by Italian Ministry of Agriculture Food and Forestry Policies [12]; and the constitution of: (i) the Slow Food presidium "Fagiolo Badda di Polizzi" [13]; (ii) the consortium "Fagiolo Badda"; (iii) the farmers' association "Fagiolo Badda di Polizzi” [14]. 
Figure 1. The small black rectangle indicates the Polizzi Generosa village in the Sicily island, where the cultivation of the "Badda" bean is practiced.

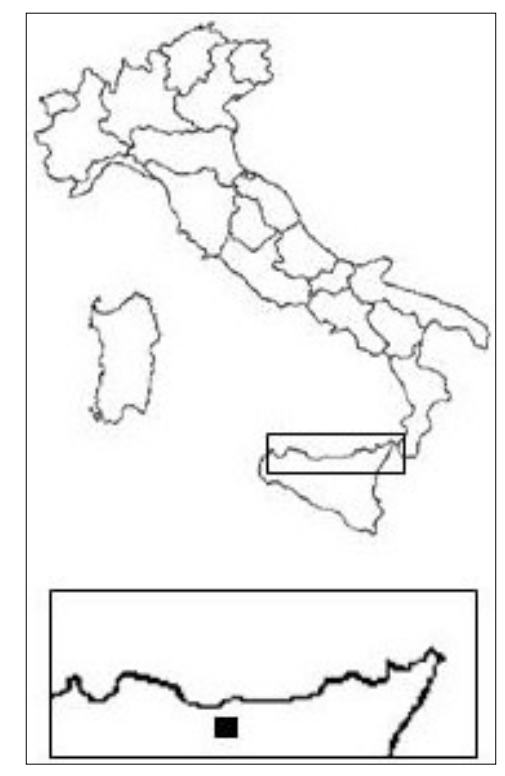

To improve the knowledge on the genetic variation present within and between "Badda nero" and "Badda bianco", seed material gathered by local farmers was investigated using biochemical and molecular markers. Phaseolin (PHAS), the major seed storage proteins of P. vulgaris, is the biochemical marker routinely used for a fast attribution of landraces to the Andean or Mesoamerican common bean gene pools [15]. Moreover, a variety of PCR-based molecular markers are useful tools for the study of common bean genetic diversity [16,17]. In particular, SSRs (Simple Sequence Repeats), or microsatellites, are short (mostly 2-4 base pair tandem repeats of DNA sequence; their polymorphism originates from a different number of repetitive core motifs present at one locus. They are useful genetic tools to construct genetic maps, to evaluate genetic diversity in commercial and local varieties, lines or genotypes of common bean $[9,18,19]$.

In the present study, PHAS and SSRs markers were used, together with the determination of some nutritional and culinary seed traits, for the characterization of the "Badda" bean.

\section{Experimental Section}

\subsection{Plant Materials}

Nine "Badda" accessions, gathered in 2006 by farmers of Polizzi Generosa (Sicily, Italy), were investigated. Four of them (PH05-PH08) belonged to the "Badda bianco" and five (PH09-PH13) to the "Badda nero" morphotype, respectively (Figure 2). Two accessions, one for each morphotype, were obtained from three different farmers, while the three accessions (PH5, PH9, and PH10) were obtained from the same farmer. A seed sample of each accession was provided by farmer's stock and was representative of the bulk from which it was extracted. 
Figure 2. Seeds of (a) the "Badda nero" and (b) the "Badda bianco" common bean.

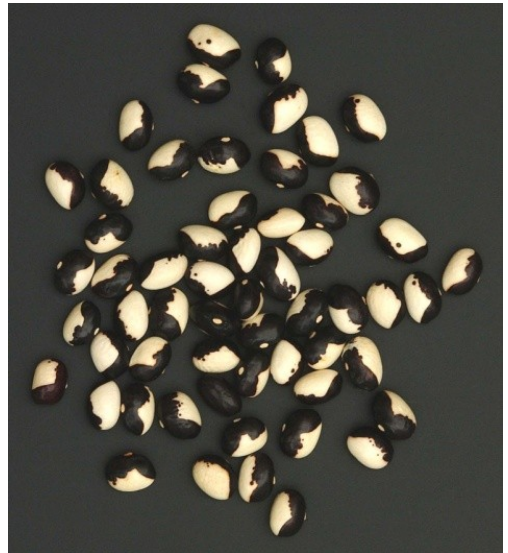

(a)

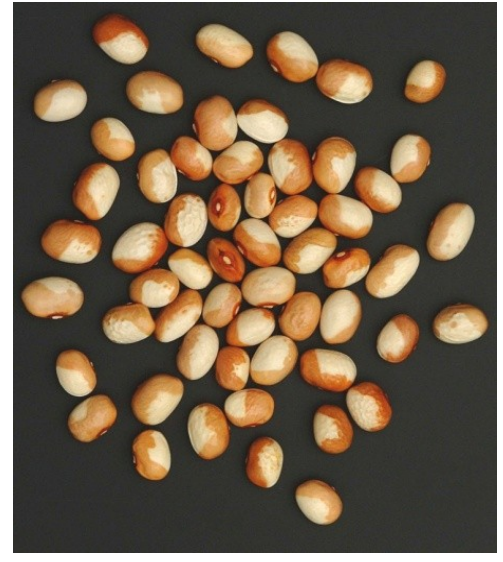

(b)

\subsection{Biochemical and Molecular Markers}

Total seed proteins were extracted from three single seeds per accession, dry cotyledons were finely ground and proteins extracted for two hours by adding 10 volumes of $0.002 \mathrm{M}$ borate buffer pH 9.0. Proteins were dissociated by heating to $90{ }^{\circ} \mathrm{C}$ for $2 \mathrm{~min}$ in presence of the denaturing buffer (20 $\mathrm{mM}$ Tris- $\mathrm{HCl} \mathrm{pH} 8.6$ containing 1\% SDS, 2\% 2-mercaptoethanol, and 8.3\% glycerol). One-dimensional SDS/PAGE was performed using 15\% polyacrylamide gel slabs [20]. For electrophoretic analyses, protein extracts of T, C, and S phaseolin pattern types were used as reference standards.

DNA was extracted from young leaves of ten individuals per accession as described by Paz and Veilleux [21]. The genetic diversity within and among the accessions was evaluated by using a total of sixteen SSR molecular markers. The list of loci, core motif, and annealing temperature is reported in Table 1. PCR was performed in a total reaction volume of $25 \mu \mathrm{L}$ containing $1.25 \mathrm{U}$ Taq DNA polymerase (5 PRIME, Hamburg, Germany), $10 \mathrm{mM}$ Tris- $\mathrm{HCl} \mathrm{pH} 8.3,50 \mathrm{mM} \mathrm{KCl,} 1.5 \mathrm{mM} \mathrm{MgCl}_{2}$, $0.25 \mathrm{mM}$ of each dNTPs, $0.05 \mu \mathrm{M}$ of each primer and $20 \mathrm{ng}$ of template DNA, using a PE 9700 Thermo Cycler (Perkin Elmer, Waltham, MA, USA). Amplifications were programmed for an initial step at $95{ }^{\circ} \mathrm{C}$ for $3 \mathrm{~min}$, followed by 35 cycles of denaturation at $94{ }^{\circ} \mathrm{C}$ for $30 \mathrm{~s}$, annealing at the required $T m$ for $30 \mathrm{~s}$ and elongation at $72{ }^{\circ} \mathrm{C}$ for $45 \mathrm{~s}$, followed by a final elongation step at $72{ }^{\circ} \mathrm{C}$ for 5 min. One SSR flanking primer for each pair was fluorescently labeled, so that amplified fragments could be visualized on an automated sequencer (CEQ 8800, Beckman-Coulter, Fullerton, CA, USA) and allelic variants at each locus determined.

\subsection{Seed Quality}

Fifty grams of dry seeds per accession were finely ground in a Cyclotec 1093 mill (Tecator, Hoganas, Sweden) and used for moisture, protein $(\mathrm{N} \times 6.25)$ and ash content measurements. All these analyses were performed according to the official AOAC methods [22]. Thirty seeds, randomly selected, were used to determine seed density, hydration and swelling indices (HI and SI, respectively), and coat percentage. Seed soaking was performed at room temperature and HI and SI measurements were done at regular time interval according to literature [23]. Forty seeds per accession were used for determination of cooking time as previously described [23]. 
Table 1. List of 16 microsatellite loci of common bean identified in the European Molecular Biology Laboratory (EMBL) nucleotide database, temperature used $(\mathrm{Tm})$, fragment size range, and number of alleles detected.

\begin{tabular}{cccccc}
\hline EMBL access. No. & Locus & Core motif & Tm & Fragment size range & $\begin{array}{c}\text { No. of } \\
\text { alleles }\end{array}$ \\
\hline AB070627 & PVSBE2 & $(\mathrm{ATA})_{8}$ & 52 & $148-194$ & 3 \\
AF402604 & HDZ1 & $(\mathrm{GAA})_{4}(\mathrm{GT})_{1}(\mathrm{ATC})_{5}$ & 55 & 198 & 1 \\
AY007525 & PVPDX1 & $(\mathrm{TC})_{6}(\mathrm{AG})_{8}$ & 50 & $158-162$ & 2 \\
J04555 & PVPVPK & $(\mathrm{CTT})_{3}(\mathrm{~T})_{3}(\mathrm{CTT})_{6}$ & 58 & $154-163$ & 2 \\
K03289 & PHVDLECB & $(\mathrm{ATGC})_{4}$ & 56 & $142-144$ & 2 \\
M68913 & PHVARC1A & $(\mathrm{ATCT})_{3}$ & 51 & 198 & 1 \\
M75856 & PVPR3A & $(\mathrm{CT})_{11}(\mathrm{TTC})_{6}$ & 57 & 157 & 1 \\
U18791 & PV18791 & $(\mathrm{TA})_{22}$ & 55 & $239-295$ & 13 \\
U34754 & PV34754 & $(\mathrm{AT})_{8}$ & 58 & $247-251$ & 2 \\
U70530 & PVU70530 & $(\mathrm{CT})_{7}$ & 52 & 245 & 1 \\
X04001 & PVGSR1 & $(\mathrm{AG})_{8}$ & 59 & 167 & 1 \\
X80051 & PVME1G & $(\mathrm{AT})_{12}$ & 57 & $194-233$ & 14 \\
X60000 & PVRBCOS & $(\mathrm{AT})_{4}(\mathrm{~T})_{2}(\mathrm{AT})_{6}$ & 55 & $135-139$ & 2 \\
X61293 & PVGLND5 & $(\mathrm{AT})_{18}$ & 50 & $154-273$ & 12 \\
X63525 & PVLOXA & $(\mathrm{AT})_{7}$ & 57 & $292-301$ & 4 \\
X96999 & PVYPR10GN & $(\mathrm{AT})_{9}$ & 57 & $170-178$ & 4 \\
\hline
\end{tabular}

\subsection{Statistical Analyses}

The average number of alleles observed per locus $\left(\mathrm{n}_{\mathrm{o}}\right)$, the effective number of alleles $\left(\mathrm{n}_{\mathrm{e}}\right)$ and the percent of polymorphic loci ( $95 \%$ criterion) were computed. The genetic diversity computed as $\mathrm{H}=1-\Sigma \mathrm{p}_{\mathrm{i}}{ }^{2}$, where pi is the frequency of the ith allele at each locus, is equivalent to the expected heterozygosity $\left(\mathrm{H}_{\mathrm{e}}\right)$ [24]. The Student's $t$-test was performed using the statistical package STATISTICA, version 7.1 (Statsoft, Tulsa, OK, USA). Based on allelic frequencies, Nei's distance matrix was used to construct a dendrogram by the UPGMA method by means of the software POPGENE, version 1.32. [25]. The levels of support for the nodes were evaluated using a bootstrap analysis with 1000 replicates, which was carried out using the POPTREE2 software [26].

\section{Results and Discussion}

Common bean landraces with bicolored seed represent a small fraction of those surviving on-farm in Italy [1]. Among the bicolored types, "Badda" bean has a preeminent position being able to boast structures, such as the "Slow Food presidium" and the "Farmers' Consortium", aimed to support the continuation of its cultivation. A detailed characterization of "Badda" bean can help to better safeguard its genetic structure, as well as to support its distinctiveness respect to other landraces or cultivars with similar coat pattern. 


\subsection{Seed Storage Protein Variation}

When analyzed by SDS/PAGE, protein extracts showed some major bands around $45 \mathrm{kDa}$, corresponding to PHAS, the major seed storage protein. The PHAS pattern type allows the attribution of landraces to the Mesoamerican or to the Andean gene pool [15]. All "Badda" accessions analyzed were homogeneous for this character, showing only the $\mathrm{C}$ phaseolin pattern type, which is associated to the Andean gene pool.

The European common beans arose from the introduction of domesticated forms from both the American gene pools. The proportions of the two gene pools within the European materials have been extensively investigated. The prevalence of Andean types was first described by Gepts and Bliss [15], and confirmed by subsequent studies at national [3,27,28] and regional [1,2,11,29] level. Probably, types belonging to the Andean gene pool, characterized by medium or large-seeded size, are widespread in Europe since they had a higher adaptation to the new environments and were preferred by both farmers and consumers [1,27]. The ratio between the two gene pools within the European germplasm is linked to geographical areas [30]. A clear-cut prevalence of Andean phaseolin types was recorded in Iberian Peninsula, Italy, and the Balkan area, while in central and south-eastern Europe, the proportion of Mesoamerican types tends to increase [31]. As concerns Italy, studies carried out at regional level, proved the presence of the three major phaseolin types $(\mathrm{C}, \mathrm{T}$, and $\mathrm{S})$. The recorded frequencies were $40 \%, 28 \%$, and $32 \%$ for $\mathrm{C}$, $\mathrm{T}$, and $\mathrm{S}$ type, respectively $[1,8,32,33]$. The $\mathrm{C}$ phaseolin type is the predominant one in Sicily as well as in other southern Italian regions $[11,34,35]$. In a recent study on twenty-five landraces cultivated in the Nebrodi mountains (northeast Sicily), the C phaseolin type was detected in 17 landraces [11].

The electrophoretic bands corresponding to phytohaemagglutinin (PHA), the lectin protein representing the second storage protein of common bean seeds, were detectable in the protein profile around $34 \mathrm{kDa}$. Eleven PHA pattern types have been described in cultivated common bean; their nomenclature was coded by Brown et al. [36]. The "Badda" accessions showed as unique PHA pattern the $\mathrm{TG}_{2}$ type. Although the gene families coding for PHAS and PHA are not linked, it has been proved that in cultivated materials there is a close association between their pattern types. Experimental results collected in this study agree with the described narrow association between $\mathrm{C}$ and $\mathrm{TG}_{2}$ patterns (PHAS and PHA protein fraction, respectively) [37].

\subsection{Genetic Variation Based on Molecular Markers}

Molecular markers of SSR type, which are specific in target, are commonly used to assess diversity among common bean landraces [19,38,39]. The polymorphism revealed by SSR markers or microsatellites was variable depending on the locus. In this study, the number of alleles per locus ranged from 1 to 14 (Table 1).

Overall, 65 alleles were identified at the 16 loci examined, with a mean of effective alleles per locus equal to 1.50 (Table 2). The mean value of the percent of polymorphic loci ( $\mathrm{P}, 5 \%$ criterion) was $32 \%$ with values ranging between $19 \%$ and $44 \%$. A particularly high level of polymorphism was observed at the locus PVME1G with 14 alleles, and at the loci PV18791 and PVGLND5 with 13 and 12 alleles, 
respectively (Table 1). The mean genetic diversity or expected heterozygosity $\left(\mathrm{H}_{\mathrm{e}}\right)$ values were calculated for each accession, and ranged from 0.27 to 0.07 , with a mean value of 0.17 (Table 2).

Table 2. Genetic diversity statistics relating to Simple Sequence Repeats (SSR) markers for each accession of "Badda" bean examined.

\begin{tabular}{cccccc}
\hline Work Code & $\mathbf{n}_{\mathbf{0}}{ }^{\mathrm{a}}$ & $\mathbf{n}_{\mathbf{e}}{ }^{\mathrm{b}}$ & $\mathbf{P}^{\mathrm{c}}$ & $\mathbf{H}_{\mathbf{e}}{ }^{\mathrm{d}}$ & $\mathbf{H}_{\mathbf{0}}{ }^{\mathrm{e}}$ \\
\hline Badda bianco & & & & & \\
\hline PH05 & 1.75 & 1.34 & 38 & 0.17 & 0.01 \\
\hline PH06 & 1.81 & 1.54 & 44 & 0.21 & 0.01 \\
\hline PH07 & 2.19 & 1.92 & 38 & 0.24 & 0.00 \\
\hline PH08 & 2.38 & 2.10 & 38 & 0.27 & 0.00 \\
\hline Mean & $2.03 *$ & 1.66 & $40 *$ & $0.22 *$ & 0.005 \\
\hline Badda nero & & & & & \\
\hline PH09 & 1.88 & 1.56 & 44 & 0.21 & 0.00 \\
\hline PH10 & 1.31 & 1.14 & 19 & 0.07 & 0.01 \\
\hline PH11 & 1.75 & 1.57 & 25 & 0.16 & 0.00 \\
\hline PH12 & 1.56 & 1.30 & 19 & 0.12 & 0.00 \\
\hline PH13 & 1.31 & 1.19 & 19 & 0.09 & 0.00 \\
\hline Mean & $1.56 *$ & 1.33 & $25 *$ & $0.13 *$ & 0.002 \\
\hline Total mean & 1.77 & 1.50 & 32 & 0.17 & 0.003 \\
\hline
\end{tabular}

${ }^{\mathrm{a}}$ mean number of observed alleles; ${ }^{\mathrm{b}}$ mean number of effective alleles; ${ }^{\mathrm{c}}$ Percentage of polymorphic loci $\left(95 \%\right.$ criterion); ${ }^{\mathrm{d}}$ Expected heterozygosity; ${ }^{\mathrm{e}}$ Observed heterozygosity; $*$ significant at $p=0.05$.

Six out of the accessions exhibited homozygosity across all loci $\left(\mathrm{H}_{\mathrm{o}}=0.0\right)$. In the others, a scarce number of heterozygotes were observed $\left(\mathrm{H}_{\mathrm{o}}\right)$, according to the predominantly autogamous mating system of common bean (Table 2). When analyzed separately, the mean values of genetic diversity parameters resulted higher for "Badda bianco", indicating that these accessions showed a higher level of genetic variability. The quantification of genetic diversity within and between "Badda bianco" and "Badda nero" bean, based on Nei's genetic diversity statistics is shown in Table 3.

Table 3. Genetic diversity statistics of "Badda" bean accessions.

\begin{tabular}{ccccc}
\hline \multirow{2}{*}{ Morphotype } & \multicolumn{4}{c}{ Nei's genetic diversity analysis } \\
\cline { 2 - 5 } & $\mathbf{H}_{\mathbf{T}}$ & $\mathbf{H}_{\mathbf{S}}$ & $\mathbf{D}_{\mathbf{S T}}$ & $\mathbf{G}_{\mathbf{S T}}$ \\
\hline Badda bianco & 0.25 & 0.22 & 0.03 & 0.12 \\
Badda nero & 0.21 & 0.13 & 0.08 & 0.38 \\
\hline
\end{tabular}

$\mathrm{H}_{\mathrm{T}}$ total genetic diversity; $\mathrm{H}_{\mathrm{S}}$ intrapopulation genetic diversity; $\mathrm{D}_{\mathrm{ST}}$ interpopulation diversity; $\mathrm{G}_{\mathrm{ST}}$ interpopulation genic differenziation coefficient.

The total genetic diversity $\left(\mathrm{H}_{\mathrm{T}}\right)$ was slightly higher in "Badda bianco". The observation that intrapopulation diversity $\left(\mathrm{H}_{\mathrm{S}}\right)$ was higher than the interpopulation genetic diversity $\left(\mathrm{D}_{\mathrm{ST}}\right)$, suggests that the diversity among accessions is lower than that within them. The coefficient of genic differentiation $\left(\mathrm{G}_{\mathrm{ST}}\right)$ among populations was 0.12 and 0.38 in "Badda bianco" and "Badda nero" bean, respectively. These results indicated that $12 \%$ of "Badda bianco" total genetic diversity is among accessions, while this value increased to $38 \%$ in "Badda nero". 
Pairwise comparison of Nei's genetic distances is reported in Table 4. The average genetic distance among the nine "Badda" accessions was 0.119 . The smaller values were observed between PH07 and PH08 (0.032), and PH11 and PH12 (0.033), belonging to "Badda bianco" and "Badda nero" bean, respectively.

Table 4. Pairwise comparison of Nei's genetic identity (above diagonal) and genetic distance (below diagonal) between common bean "Badda" accessions.

\begin{tabular}{cccccccccc}
\hline Accession & PH05 & PH06 & PH07 & PH08 & PH09 & PH10 & PH11 & PH12 & PH13 \\
\hline PH05 & - & 0.943 & 0.924 & 0.919 & 0.894 & 0.771 & 0.871 & 0.866 & 0.777 \\
PH06 & 0.059 & - & 0.960 & 0.951 & 0.879 & 0.808 & 0.901 & 0.889 & 0.820 \\
PH07 & 0.079 & 0.041 & - & 0.969 & 0.921 & 0.842 & 0.935 & 0.939 & 0.856 \\
PH08 & 0.084 & 0.051 & 0.032 & - & 0.910 & 0.878 & 0.913 & 0.905 & 0.899 \\
PH09 & 0.112 & 0.123 & 0.082 & 0.095 & - & 0.819 & 0.946 & 0.939 & 0.830 \\
PH10 & 0.260 & 0.213 & 0.172 & 0.130 & 0.200 & - & 0.876 & 0.825 & 0.963 \\
PH11 & 0.138 & 0.102 & 0.067 & 0.091 & 0.055 & 0.133 & - & 0.968 & 0.886 \\
PH12 & 0.143 & 0.117 & 0.063 & 0.100 & 0.062 & 0.192 & 0.033 & - & 0.840 \\
PH13 & 0.252 & 0.198 & 0.156 & 0.106 & 0.186 & 0.037 & 0.121 & 0.174 & - \\
\hline
\end{tabular}

The UPGMA dendrogram, based on Nei's genetic distances as defined by SSR markers, is shown in Figure 3. The nine "Badda" accessions were grouped in three sub-clusters. The first one included all the "Badda bianco" accessions, while the "Badda nero" ones were grouped in two well-distinguished sub-clusters. The PH10 and PH13 accessions, located in a well-separated branch, showed fairly different results than the other materials analyzed, thus indicating more distant genetic relationships with the other two groups (see Table 4).

Figure 3. Dendrogram based on Nei's genetic distances as defined by SSR markers showing the genetic relationships among the "Badda" bean accessions. Support values are shown.

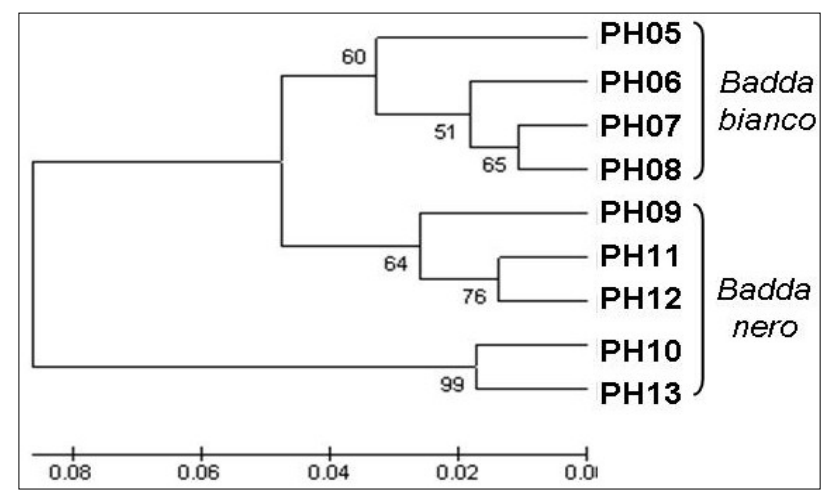

Recently, Paniconi et al. [10] studied three "Badda" bean accessions using morpho-physiological traits and ISSR (Inter Simple Sequence Repeat) molecular markers. Although different accessions and marker types were used, they also recorded the presence of a more distant population among the three analyzed and attributed this result to a different introduction or contamination by foreign germplasm. Results presented in this study confirm the possibility that two constitutive nuclei contributed to the genetic background of "Badda nero" bean. The co-existence of two or more nuclei within a single landrace was described for "Fagiolo del Purgatorio", an Italian landrace traditionally cultivated in 
Central Italy [19]. The authors reported that the differences between the two nuclei identified within "Fagiolo del Purgatorio" were at agronomic, biochemical, morphological and genetic level. It is interesting to underline that this landrace belongs to the Mesoamerican gene pool, suggesting that the presence of more nuclei within the same landrace could not be prerogative of the Andean gene pool. To explain the co-existence of different nuclei within a landrace, different scenarios can be hypothesized: (a) genetically different individuals were already present in the original material; (b) presently detectable different nuclei are the result of selection processes operated over the time by environment and/or farmers; (c) introduction of foreign materials, morphologically similar to the original one, has occurred.

\subsection{Nutritional and Technological Seed Traits}

The nutritional and technological seed quality of the "Badda" bean were investigated by analyzing nine traits. As shown in Table 5, for all traits the range of variation relative to "Badda bianco" and "Badda nero" bean overlapped to a great extent. This suggests that the two "Badda" bean morphotypes have a comparable seed quality.

Table 5. Grain quality traits. Seed composition values are referred to dry matter.

\begin{tabular}{|c|c|c|c|c|c|c|c|c|c|c|}
\hline \multirow{2}{*}{$\begin{array}{l}\text { Work } \\
\text { code }\end{array}$} & \multirow{2}{*}{$\begin{array}{c}100 \text { seed } \\
\text { weight }(\mathrm{g})\end{array}$} & \multirow{2}{*}{$\begin{array}{c}\text { Seed } \\
\text { density } \\
\left(\mathrm{g} \mathrm{mL}^{-1}\right)\end{array}$} & \multirow{2}{*}{$\begin{array}{c}\text { Coat } \\
\left(\mathrm{g} \mathrm{kg}^{-1}\right)\end{array}$} & \multicolumn{2}{|c|}{ HI (\%) } & \multirow{2}{*}{$\begin{array}{c}\text { SI } \\
(\% 24 \text { h })\end{array}$} & \multirow{2}{*}{$\begin{array}{c}\text { Moisture } \\
\left(\mathrm{g} \mathrm{kg}^{-1}\right)\end{array}$} & \multirow{2}{*}{$\begin{array}{l}\text { Protein } \\
\left(\mathrm{g} \mathrm{kg}^{-1}\right)\end{array}$} & \multirow{2}{*}{$\begin{array}{c}\text { Ash } \\
\left(\mathrm{g} \mathrm{kg}^{-1}\right)\end{array}$} & \multirow{2}{*}{$\begin{array}{c}\text { Cooking } \\
\text { time } \\
\text { (min) }\end{array}$} \\
\hline & & & & $5 \mathrm{~h}$ & $24 \mathrm{~h}$ & & & & & \\
\hline \multicolumn{11}{|c|}{ Badda bianco } \\
\hline PH05 & 56.2 & 1.20 & 59.2 & 45.4 & 106.4 & 100 & 111.2 & 258.0 & 47.7 & 41 \\
\hline PH06 & 44.2 & 1.07 & 57.6 & 2.5 & 80.1 & 92 & 108.7 & 243.8 & 41.0 & 42 \\
\hline $\mathrm{PH} 07$ & 46.5 & 1.26 & 56.0 & 4.4 & 87.4 & 136 & 110.4 & 232.7 & 40.6 & 42 \\
\hline PH08 & 52.2 & 1.13 & 52.8 & 15.2 & 89.7 & 92 & 101.7 & 245.7 & 46.1 & 45 \\
\hline Mean & 49.8 & 1.16 & 56.4 & 16.9 & 91 & 105 & 108.0 & 245.0 & 43.8 & 42.5 \\
\hline Std Dev & 5.45 & 0.08 & 2.73 & 19.82 & 11.11 & 21.01 & 4.33 & 10.36 & 3.59 & 1.73 \\
\hline \multicolumn{11}{|c|}{ Badda nero } \\
\hline PH09 & 45.7 & 1.27 & 59.1 & 12.5 & 87.0 & 127 & 110.2 & 242.0 & 42.0 & 38 \\
\hline PH10 & 59.1 & 1.09 & 57.0 & 59.7 & 85.5 & 94 & 106.5 & 243.1 & 38.8 & 44 \\
\hline PH11 & 44.1 & 1.10 & 59.3 & 8.2 & 87.9 & 75 & 112.5 & 224.8 & 40.9 & 42 \\
\hline PH12 & 41.7 & 1.11 & 60.5 & 5.6 & 90.4 & 100 & 111.3 & 222.7 & 43.0 & 48 \\
\hline PH13 & 59.3 & 1.18 & 57.1 & 30.2 & 92.4 & 123 & 103.1 & 249.4 & 45.8 & 50 \\
\hline Mean & 50.0 & 1.15 & 58.6 & 23.2 & 88.6 & 104 & 108.7 & 236.4 & 42.1 & 44.4 \\
\hline Std Dev & 8.54 & 0.08 & 1.51 & 22.53 & 2.75 & 21.49 & 3.86 & 11.91 & 2.59 & 4.78 \\
\hline
\end{tabular}

$\mathrm{HI}=$ Hydration Index; SI = Swelling Index.

The 100 seed weight, ranging from 42 to $59 \mathrm{~g}$, is in agreement with its assignation to Andean gene pool, that generally contains large-seeded types. The coat content showed a low variation (52.8-60.5 $\mathrm{g} \mathrm{kg}^{-1}$ ), and was not related to seed size. It is well known that common bean seeds need a period of soaking before cooking, and that short soaking times are preferred by consumers. On the base of $\mathrm{HI}$ values recorded after $5 \mathrm{~h}$ of soaking, the "Badda" accessions can be divided in two groups (Table 5). The first one was constituted by accessions having a very low hydration rate $(\mathrm{HI} \leq 30 \%)$, 
while the second comprised the accessions PH05 and PH10 that had high hydration rates (HI $\geq 45 \%$ ). The detection of low and high HI values within both "Badda bianco" and "Badda nero" bean indicated that hydration rate was not related to coat color. The detection of genotypes having high hydration rates could discourage the cultivation of those that do not possess this trait. However, a similar choice is questionable in relation to genetic resources safeguard, which is devoted to the conservation of the original genetic background of a landrace. The difference of hydration rate among the accessions disappeared when the soaking time was long as $24 \mathrm{~h}$ (Table 5). At that time, seeds have absorbed as much water as almost their dry weight $(\mathrm{HI}>80 \%)$. Moreover, prolonged soaking allowed a high increase of seed size ( $\mathrm{SI}>90 \%$ ), with the only exception of PH11 accession ( $\mathrm{SI}=75 \%$ ).

As predictable for large seeds, high cooking times were recorded for the "Badda" bean, though this trait was shown not to be significantly correlated to seed size. Mean cooking time value of "Badda nero" slightly exceeded that of "Badda bianco" (Table 5). In order to estimate the nutritional quality of "Badda" bean, the protein content was determined. This trait varied little among the accessions $(\mathrm{CV} \leq 5 \%)$, but is significantly correlated to 100 seed weight $(\mathrm{R}=0.74, p<0.05)$. The highest value was recorded for the "Badda bianco" PH05, while the lowest one was that of the "Badda nero" PH12. Finally, ash content showed a low degree of variation, from 38.8 to $47.7 \mathrm{~g} \mathrm{~kg}^{-1}$, and the calculated CV was $\leq 8.2 \%$.

When the "Badda" seed quality traits were compared with those relative to 25 landraces traditionally grown in northeast Sicily, it appears a certain resemblance with the landrace named "Monaca" [11]. In detail, the percentage of coat, protein, and ash were comparable, while 100 seed weight, cooking time and $\mathrm{HI}$ after 5 and $24 \mathrm{~h}$ of soaking, showed differences.

Seed morphology of "Badda" bean results attractive for consumers being a round large-seeded type with partially colored coat. It is widely accepted that only some landraces surviving on-farm possess quality traits that can justify their promotion as niche products. Consumers are attracted by visual, textural, and sensory seed traits. Nutritionists focused their attention on the evaluation of the main seed components, as well as on the minor ones having potential nutraceutical value. Data reported in this study, far from a complete nutritional evaluation of the "Badda" bean, represents a starting point for its promotion as niche product.

\section{Conclusions}

Italian common bean germplasm is characterized by a high degree of genetic diversity, as a result of five centuries of uninterrupted cultivation and unconscious selection, in addition to a capillary diffusion of this crop. As a consequence of a wide diversification, the overall number of Italian accessions stored ex-situ, and landraces still surviving on-farm, is remarkable. Taking this into account, only a multidisciplinary approach can be fully effective to characterize this precious material and to help plan adequate safeguard actions. Economic motivations, such as the commercialization of landraces as niche products, are fundamental to encourage young farmers and local communities to participate in initiatives of on-farm conservation. However, the market requirements as well as the constraints to obtain one of the European quality marks could encourage the selection of some genotypes, modifying irremediably the original genetic structure. In this frame, the questions related to the safeguard of a landrace characterized by a complex genetic structure, such as the "Badda" bean, become relevant. 


\section{Acknowledgments}

The authors thank B. Campion for contributing seed samples and S. Puglisi for his suggestions on statistical analyses. Research supported by Ministry of Agriculture Food and Forestry Policies with funds released by Comitato Interministeriale per la Programmazione Economica (CIPE) (resolution 17/2003).

\section{Conflicts of Interest}

The authors declare no conflict of interest.

\section{References}

1. Piergiovanni, A.R.; Lioi, L. Italian common bean landraces: History, genetic diversity and seed quality. Diversity 2010, 2, 837-862.

2. Escribano, M.R.; Santalla, M.; Casquero, P.A.; de Ron, A.R. Patterns of genetic diversity in landraces of common bean (Phaseolus vulgaris L.) from Galicia. Plant Breed. 1998, 117, 49-56.

3. Rodiño, A.P.; Santalla, M.; Montero, I.; Casquero, P.A.; de Ron, A.M. Diversity of common bean (Phaseolus vulgaris L.) germplasm from Portugal. Genet. Resour. Crop Evol. 2001, 48, 409-417.

4. Mavromatis, A.G.; Arvanitoyannis, I.S.; Korkovelos, A.E.; Giakountis, A.; Chatzitheodorou, V.A.; Goulas, C.K. Genetic diversity among common bean (Phaseolus vulgaris L.) Greek landraces and commercial cultivars: Nutritional components, RAPD and morphological markers. Span. J. Agric. Res. 2010, 8, 986-994.

5. Ganopoulos, I.; Bosmali, I.; Madesis, P.; Tsaftari, A. Microsatellite genotyping with HRM (High Resolution Melting) analysis for identification of the PGI common bean variety Plake Megalosperma Prespon. Eur. Food Res. Technol. 2012, 234, 501-508.

6. Montesano, V.; Negro, D.; Sarli, G.; Logozzo, G.; Spagnoletti Zeuli, P.L. Landraces in inland of the Basilicata region, Italy: Monitoring and perspectives for on farm conservation. Genet. Resour. Crop Evol. 2012, 59, 701-716.

7. Negri, V.; Tosti, N. Phaseolus genetic diversity maintained on-farm in central Italy. Genet. Resour. Crop Evol. 2002, 49, 511-520.

8. Angioi, S.A.; Rau, D.; Rodriguez, M.; Logozzo, G.; Desiderio, F.; Papa, R.; Attene, G. Nuclear and chloroplast microsatellite diversity in Phaseolus vulgaris L. from Sardinia (Italy). Mol. Breed. 2009, 23, 413-429.

9. Mercati, F.; Leone, M.; Lupini, A.; Sorgonà, A.; Bacchi, M.; Abenavoli, M.R.; Sunseri, F. Genetic diversity and population structure of a common bean (Phaseolus vulgaris L.) collection from Calabria (Italy). Genet. Resour. Crop. Evol. 2013, 60, 839-852.

10. Paniconi, G.; Gianfilippi, F.; Mosconi, P.; Mazzuccato, A. Distinctiveness of bean landraces in Italy: The case study of the "Badda" bean. Diversity 2010, 2, 701-716.

11. Lioi, L.; Nuzzi, A.; Campion, B.; Piergiovanni, A.R. Assessment of genetic variation in common bean (Phaseolus vulgaris L.) from Nebrodi mountains (Sicily, Italy). Genet. Resour. Crop Evol. 2012, 59, 455-464. 
12. Tredicesima revisione dell'elenco dei prodotti agroalimentari tradizionali. Available online: http://www.politicheagricole.it/flex/cm/pages/ServeBLOB.php/L/IT/IDPagina/3276 (accessed on 4 October 2013).

13. Fondazione Slow Food. I presidi Slow Food in Italia. Available online: http://www.fondazioneslowfood.it/pagine/ita/presidi_italia/dettaglio_presidi.lasso?-id=3545 (accessed on 4 October 2013).

14. Comune di Polizzi Generosa. Available online: http://www.comune.polizzi.pa.it/index.php? option=com_alberghi\&Itemid=130\&task=viewcategory\&catid=68 (accessed on 4 October 2013).

15. Gepts, P.; Bliss, F.A. Dissemination pathways of common bean (Phaseolus vulgaris, Fabaceae) deduced from phaseolin electrophoretic variability. II. Europe and Africa. Econ. Bot. 1988, 42, 86-104.

16. Maciel, F.L.; Echeverrigaray, S.; Gerald, L.T.S.; Grazziotin, G.F. Genetic relationships and diversity among Brazilian cultivars and landraces of common bean (Phaseolus vulgaris L.) revealed by AFLP markers. Genet. Resour. Crop Evol. 2003, 50, 887-893.

17. Blair, M.W.; Giraldo, M.C.; Buendia, H.F.; Tovar, E.; Duque, M.C.; Beebe, S.E. Microsatellite marker diversity in common bean (Phaseolus vulgaris L.). Theor. Appl. Genet. 2006, 113, $100-109$.

18. Grisi, M.C.; Blair, M.W.; Gepts, P.; Brondani, C.; Pereira, P.A.; Brondani, R.P. Genetic mapping of a new set of microsatellite markers in a reference common bean (Phaseolus vulgaris) population BAT93 x Jalo EEP558. Genet. Mol. Res. 2007, 30, 691-706.

19. Lioi, L.; Piergiovanni, A.R.; Pignone, D.; Puglisi, S.; Santantonio, M.; Sonnante, G. Genetic diversity of some surviving on-farm Italian common bean (Phaseolus vulgaris L) landraces. Plant Breed. 2005, 124, 576-581.

20. Bollini, R.; Chrispeels, M.J. Characterization and subcellular localization of vicilin and phytohemagglutinin, the two major reserve proteins of Phaseolus vulgaris L. Planta 1978, 142, 291-298.

21. Paz, M.M.; Veilleux, R.E. Genetic diversity based on randomly amplified polymorphic DNA (RAPD) and its relationship with the performance of diploid potato hybrids. J. Am. Soc. Hort. Sci. 1997, 122, 740-747.

22. Association of Official Agricultural Chemists (AOAC). Official Methods of Analysis, 11th ed.; AOAC: Washington, DC, USA, 1970.

23. Piergiovanni, A.R.; Cerbino, D.; della Gatta, C. Diversity in seed quality traits of common bean (Phaseolus vulgaris L.) populations from Basilicata (Southern Italy). Plant Breed. 2000, 119, 513-516.

24. Nei, M. Estimation of average heterozygosity and genetic distance from a small number of individuals. Genetics 1978, 89, 583-590.

25. Yeh, F.C.; Yang, R.C.; Boyle, T. POPGENE, version 1.32; Microsoft Window-based freeware for population genetic analysis; Available online: http://www.ualberta.ca/ fyeh/popgene download.html (accessed on 4 December 2013).

26. Takezaki, N.; Nei, M.; Tamura, K. POPTREE2: Software for constructing population trees from allele frequency data and computing other population statistics with windows interface. Mol. Biol. Evol. 2010, 27, 747-752. 
27. Lioi, L. Geographical variation of phaseolin pattern in an old world collection of Phaseolus vulgaris. Seed Sci. Technol. 1989, 17, 317-324.

28. Ocampo, C.H.; Martin, J.P.; Sanchez-Yelamo, M.D.; Ortiz, J.M.; Toro, O. Tracing the origin of Spanish common bean cultivars using biochemical and molecular markers. Genet. Resour. Crop Evol. 2005, 52, 33-40.

29. Sicard, D.; Nanni, L.; Porfiri, O.; Bulfon, D.; Papa, R. Genetic diversity of Phaseolus vulgaris L. and P. coccineus L. landraces in central Italy. Plant Breed. 2005, 124, 464-472.

30. Bellucci, E.; Bitocchi, E.; Rau, D.; Rodriguez, M.; Biagetti, E.; Giardini, A.; Attene, G.; Nanni, L.; Papa, R. Genomics of Origin, Domestication and Evolution of Phaseolus vulgaris. In Genomics of Plant Genetic Resources; Tuberosa, R., Graner, A., Frison, E., Eds.; Springer: Dordrecht, The Netherlands, 2014; Volume 1, pp. 483-507.

31. Angioi, S.A.; Rau, D.; Nanni, L.; Bellucci, E.; Papa, R.; Attene, G. The genetic make-up of the European landraces of the common bean. Plant Genet. Resour. 2011, 9, 197-201.

32. Logozzo, G.; Donnoli, R.; Macaluso, L.; Papa, R.; Knupffer, H.; Spagnoletti Zeuli, P.L. Analysis of the contribution of Mesoamerican and Andean gene pools to European common bean (Phaseolus vulgaris L.) germplasm and strategies to establish a core collection. Genet. Resour. Crop Evol. 2007, 54, 1763-1779.

33. Perazzini, R.; Leonardi, D.; Ruggeri, S.; Alesiani, D.; D’Arcangelo, G.; Canini, A. Characterization of Phaseolus vulgaris L. landraces cultivated in central Italy. Plant Foods Hum. Nutr. 2008, 63, 211-218.

34. Limongelli, G.; Laghetti, G.; Perrino, P.; Piergiovanni, A.R. Variation of seed storage proteins in landraces of common bean (Phaseolus vulgaris L.) from Basilicata, southern Italy. Euphytica 1996, 92, 393-399.

35. Piergiovanni, A.R.; Maruca, G.; Lioi, L. Biochemical Characterization of Common Bean Germplasm Maintained On-Farm in Calabria Region. In Proceedings of the IX Convegno Nazionale sulla Biodiversità, Valenzano, Italy, 5-7 September 2012.

36. Brown, J.W.S.; Osborn, T.C.; Bliss, F.A.; Hall, T.C. Bean lectins. Part 1: Relationships between agglutinating activity and electrophoretic variation in the lectin-containing G2/albumin seed proteins of French bean (Phaseolus vulgaris L.). Theor. Appl. Genet. 1982, 62, 263-271.

37. Lioi, L. Electrophoretic variation and geographical distribution of the seed protein phytohemagglutinin in cultivated Phaseolus vulgaris L. J. Genet. Breed. 1991, 45, 97-102.

38. Blair, M.W.; González, L.F.; Kimani, P.M.; Butare, L. Genetic diversity, inter-gene pool introgression and nutritional quality of common beans (Phaseolus vulgaris L.) from Central Africa. Theor. Appl. Genet. 2010, 121, 237-248.

39. Burle, M.L.; Fonseca, J.R.; Kami, J.A.; Gepts, P. Microsatellite diversity and genetic structure among common bean (Phaseolus vulgaris L.) landraces from Brazil, a secondary center of diversity. Theor. Appl. Genet. 2010, 12, 801-813.

(C) 2013 by the authors; licensee MDPI, Basel, Switzerland. This article is an open access article distributed under the terms and conditions of the Creative Commons Attribution license (http://creativecommons.org/licenses/by/3.0/). 